\title{
Complex Noun Phrases in Polish-English Translation: Evidence from Three Registers
}

\begin{abstract}
The present paper is a study of techniques utilized in the rendering of complex grammatical structures in Polish-English non-literary translation. Given that nominal style is more pervasive in Polish than in English non-fiction registers (cf. Lewandowski 2015), this contribution aims to identify translation procedures that are most commonly applied in re-expressing elaborate Polish noun phrases in English. To this aim, three domain-specific translation corpora have been created. Their analysis has found that regardless of text type, the translators typically employ three procedures: 1) reduction of NP constituents, such as nouns, participles, and relativizers, 2) recategorization (primarily denominalization), and 3) recasting, i.e. changing the order of NP constituents. While these procedures are sometimes combined, it is the first one that is most frequently applied in the translation process.
\end{abstract}

\section{Key words}

Polish-English translation; noun phrases; translation procedures; Polish-English contrastive grammar; non-literary translation; translation teaching

\section{Introduction}

Elaborate noun phrases are a distinctive feature of a wide range of written registers and genres, such as: research articles, newspaper prose as well as legal, administrative, political or technical texts. Since numerous premodifiers and postmodifiers can be added to head nouns (HNs), ${ }^{1}$ the aforementioned text types exhibit high informational density. Putting information into noun-headed phrases is indicative of strong nominalization tendencies that are so prevalent in many 
Indo-European languages that they can be regarded as instances of functionalstylistic universals (cf. Radovanović 2001: 43). As a result of nominalization, which is viewed by Halliday (1994) in terms of grammatical metaphor, processes are conceptualized as things. According to Libura (2000), who draws on these views, extensive use of nominalization yields a static image of the world reflected in language.

Given the structural differences among languages, elaborate NPs can pose a real challenge in translation as they contribute to the syntactic complexity of texts that need to be rendered in another language. While the process of translation primarily consists in transferring meaning rather than single words or phrases, and is a multifaceted operation involving several (sub)skills or competences (cf., e.g., Schäffner 2000), it is hard to deny that professional translators ought to be able to adequately re-express SL grammatical structures in the TL. To succeed in this, they need to demonstrate linguistic competence in the languages concerned (i.e., good knowledge of contrastive grammar) and transfer competence.

In a previous paper (Lewandowski 2015) I demonstrated that Polish syntax shows a higher preference for nominal means of expression in two major non-fiction registers, i.e. news and research articles. In the light of these findings, I discussed the significance of denominalization in Polish-English translation, and showed that this procedure can be successfully applied in the translation of highly nominalized sentences into English. The present contribution is intended to offer a broader perspective: drawing upon evidence from three domain-specific corpora of Polish texts and their English translations, it aims to demonstrate how complex Polish NPs are rendered in English. In view of the fact that the linear order of constituents within Polish NPs is more fixed than sentence word order (Gębka-Wolak 2000: 144), the present paper will try to provide an answer to the following question: is it feasible to arrive at a set of techniques that various professional translators resort to as they try to manage difficult and elaborate nominal structures in Polish-English translation? Prior to discussing such translational operations, however, it is first necessary to analyze the structure of Polish and English NPs.

\section{Major structural differences between Polish and English NPs}

The following overview is based on the views of Jodłowski (1976), Quirk et al. (1985), Biber et al. (1999), Gębka-Wolak (2000), as well as Majchrzak (1978), Fisiak et al. (1978), Willim and Mańczak-Wohlfeld (1997), and Kucelman (2012), who investigated Polish and English NPs from a contrastive perspective. Of particular relevance to the ensuing discussion will be all references to Biber et al. (1999) as their claims are supported by quantitative findings from a six-year research project into the patterns of English grammar usage across four major registers: conversation, news reportage, academic prose, and fiction.

In terms of major types of modification, English and Polish noun phrases exhibit a moderate degree of similarity. In both languages, HNs can be preceded by 
some pronouns, numerals, general adjectives as well as present and past participles. The common forms of postmodification include prepositional phrases, relative clauses, participle clauses, noun complement clauses, participles, appositive noun phrases, ${ }^{2}$ and adverbs. ${ }^{3}$

The first major difference concerns the basic structure of NPs in both languages. In English, a singular countable common noun in head position needs to be preceded by a determiner (i.e. an article, a demonstrative, a quantifier, or a possessive), which in Polish is not an obligatory constituent of NPs. ${ }^{4}$ Determiners are mutually exclusive within English NPs (except for some quantifiers). No such restrictions hold for equivalent Polish categories, which can co-occur inside NPs (Eng. *This my boyfriend vs. Pol. Ten mój chłopak).

As regards more complex nominal structures, in English, head nouns can additionally be premodified by other nouns to form the so-called noun + noun sequences, some of which constitute noun compounds. According to Biber et al. (1999: 589-591), such combinations, which express a multitude of semantic relationships in a concise manner, are the second most frequent type of premodification (after general adjectives and before present and past participles). Additionally, English nouns (predominantly animate nouns) are modified by genitives in attributive position. The uninflected noun + noun structure does not occur in Polish ${ }^{5}$ whereas attributive genitives, are rare and thus can be regarded as marked, e.g. Roberta ksiażka (Robert's book).

In Polish, the genitive case-marked noun canonically occurs right after the head noun, e.g. ksiażka Roberta or filizanka herbaty (a cup of tea). As shown by the latter example, the head noun + genitive sequence (NG) often corresponds to an of-phrase in English (especially if the genitive is an inanimate noun). The Polish NG structure is also rendered by a noun + noun sequence, e.g. nauczyciel historii $\rightarrow$ history teacher or pas bezpieczeństwa $\rightarrow$ safety belt. Polish HNs can also be postnominally modified by nouns in the dative and locative, e.g. pomoc uchodźcom (aid to the refugees) or rzut oszczepem (javelin throw). However, these co-occurrence patterns are less common than the NG construction. Head nouns are also directly followed by adjectival modifiers, especially "when they refer to some intrinsic, or type, feature of the object denoted by the noun phrase, rather than to some incidental (temporal) or individual one" (Fisiak et al. 1978: 81), e.g. strajk wloski (Italian strike). This rule does not apply to English nouns, which are very rarely postmodified by adjectives. By contrast, in English, some nouns are followed by infinitive clauses, as in a chance to win the race, a pattern which is practically non-existent in Polish. ${ }^{6}$

In English, the order of NP constituents is more fixed than in Polish because their grammatical functions are indicated by the positions they occupy within NPs. Special rules apply even to adjective order, which is not the case with Polish adjectival modifiers as they can be arranged more freely. It can be safely generalized that since syntactic functions in Polish are morphologically marked by case suffixes, some determiners and modifiers occur in both pre- and post-head positions. For instance, demonstratives can either precede or follow the HN, e.g. ten 
problem or problem ten (this problem). Complex modifiers can change their position from postnominal to prenominal. It is possible to shift multiple postmodifiers to attributive position, e.g. utwór, skomponowany przez mato znanego artyste (the piece, composed by a little-known artist) $\rightarrow$ skomponowany przez mało znanego artyste utwór (*the composed by a little-known artist piece) or rodzic uwaznie obserwujacy swoje dziecko (a parent closely watching their child) $\rightarrow$ uwazinie obserwujacy swoje dziecko rodzic (*a closely watching their child parent). This kind of transformation occurs as a result of the Relative Clause Reduction and the Adjectival VP Shift (Fisiak et al. 1978: 82-83). In English, it can only be applied when the shifted phrase is composed solely of either an adjective or a participle. Polish syntax is much less constrained in this respect as the shifted modifier, whose word order often remains unchanged, can contain a prepositional phrase, or an object and an adverb combination. However, it would be far-fetched to argue that in Polish the order of modifiers is not governed by any rules. In fact, as many authors claim, it can be regulated by grammatical, formal, semantic and pragmatic factors (cf. Szober 1963; Majchrzak 1978; Szwedek 1981; Willim and Mańczak-Wohlfeld 1997; Gębka-Wolak 2000; Scheffler 2008). ${ }^{7}$

From the above discussion it follows that major structural differences concern adjectival and noun modifiers and are strongly related to the order of constituents within complex NPs. Hence, it seems legitimate to argue that multiple modification in noun-headed phrases can pose challenges in Polish-English translation. The following section will demonstrate how these problems are handled by professional translators.

\section{Procedures in the translation of complex NPs}

For the purpose of this study, three small corpora of Polish texts and their English translations have been created. Each corpus totals around 20,000 words in terms of the overall size of the source texts. The first one includes three research papers in linguistics (RP). The second one features texts from the websites of three major Polish companies: Orlen, KGHM and PZU (for the sake of convenience, henceforth referred to as company profiles - CP). Finally, the last one is a bilingual tourist album and guide about Poland (TG). More detailed information about the corpus sources can be found in the References.

All of these text types are marked by a relatively high level of informational density, which in purely linguistic terms translates into the pervasiveness of nounphrase structures with multiple modification. Nouns and adjectives significantly outnumber verbs and adverbs. According to Gajda (2001: 188), nouns account for approximately $40 \%$ of all words in Polish academic prose texts, while adjectives for about $20 \%$. By contrast, verbs constitute only $10 \%$ of words in academic discourse. Similar proportions seem to hold for the remaining text types. As regards texts from the remaining two registers, due to the lack of quantitative findings, the data from the $\mathrm{CP}$ and $\mathrm{TG}$ corpora have been used to compute the percentages 
of the word classes in question. ${ }^{8}$ As it turns out, both kinds of texts contain a high number of nouns ( $44 \%$ in the $\mathrm{CP}$ corpus, and $38 \%$ in the TG corpus), compared to the mean percentages of verbs ( $8 \%$ and $10 \%$, respectively). Adjectives constitute $21 \%(\mathrm{CP})$ and $23 \%(\mathrm{TG})$ of all words.

By packing information into complex noun phrases, text authors impose a burden on their readers, who may sometimes need to take time to understand the text properly (cf. Biber 2003). In view of this, translators need to make sure that the texts they produce are not only in line with the stylistic and syntactic conventions of the target language, but are also comprehensible to target readers. In trying to achieve this objective, as they grapple with structural complexities, they utilize three major procedures, which will be discussed below.

Prior to analysis, however, a brief explanation of the data presentation format, including typographic conventions, is required. All SL examples and their translations are presented in tables. The NPs subjected to analysis are enclosed in square brackets with HNs underscored. Parentheses, in turn, indicate clauses into which some of the NPs from the SL have been expanded (see 3.2). The key constituents that have undergone changes in the process of translation have been boldfaced.

\subsection{NP reduction}

In her paper on conciseness in translation, Konefał (2013: 73-74) compares and contrasts several translation theory terms that are related to redundancy in the translation process. Four of them have been defined by Delisle et al. (1999) in their dictionary of translation terms. Implicitation is "[a] translation procedure intended to increase the economy of the target text, and achieved by not explicitly rendering elements of information from the source text in the target text when they are evident from the context or the described situation can be readily inferred by the speakers of the target language" (1999: 145). Concentration is "[a] decrease in the number of elements used in the target language to express the same semantic content as compared to the parallel segment in the source text" (1999: 127). If applied as a translation procedure, concentration results in concision "a stylistic effect resulting from the re-expression of an idea in the target text in fewer words than are used in the source text, thus producing a more economical text in the target language" (1999: 127). These concepts should not be confused with omission, which is defined as "a translation error where the translator fails to render a necessary element of information from the source text in the target text" (1999: 165). ${ }^{9}$

Let us now relate these terms to the subject matter of this subsection. Implicitation, as defined by Delisle et al., primarily entails removing pieces of information that are not culturally relevant from the target user's perspective, ${ }^{10}$ which is why, in my view, it should not be invoked in the context of purely structural (linguistic) operations. Omission, being a translation error, should not be employed as a pertinent concept in the ensuing discussion, either. Concentration, in contrast, comes 
closest to the procedure described in this subsection as it results in the elimination of redundant words, e.g. repetitions or pleonasms. Interestingly, concentration frequently occurs in translation into English: "[g]enerally speaking, non-English texts contract when translated into English" (Delisle et al. 1999: 127). In the case of complex NPs, concentration leads to the reduction (removal) of their constituents.

The analysis of corpus data has found that complex NP reduction primarily involves deleting words from three categories: nouns, participles and relativizers. The following is an illustration of such translational operations along with brief discussion.

\section{(a) Noun deletion}

\begin{tabular}{|c|c|l|l|}
\hline No. & Corpus & \multicolumn{1}{|c|}{ Polish example } & \multicolumn{1}{|c|}{ English translation } \\
\hline 1. & CP & $\begin{array}{l}\text { Prezentacja wyników finansowych } \\
\text { Grupy PZU za IV kwartał i pełny rok } \\
\text { 2011] }\end{array}$ & {$\left[\begin{array}{l}\text { [PZU Group's Q4 and full year 2011 } \\
\text { financial results] }\end{array}\right.$} \\
\hline 2. & TG & $\begin{array}{l}\text { Spośród najbardziej znanych skałek, } \\
\text { leżących na [terenie Karkonoskiego } \\
\text { Parku Narodowego], najciekawsze są } \\
\text { Pielgrzymy. }\end{array}$ & $\begin{array}{l}\text { The best known rocks in [the Park] in- } \\
\text { clude the Pilgrims }\end{array}$ \\
\hline 3. & RP & $\begin{array}{l}\text { Wśród kompleksów pytajnych } \\
\text { powtarzają się struktury tematyczne } \\
\text { związane z [okresem Wielkiego Postu] }\end{array}$ & $\begin{array}{l}\text { Among the interrogative sentence sets, } \\
\text { themes relating to [Lent] reoccur }\end{array}$ \\
\hline
\end{tabular}

Table 1. Examples of noun deletion in Polish-English translation

In each case, the boldfaced items indicate SL nouns that have been deleted in translation, i.e. they have not been rendered in the TL by means of equivalent noun forms. Example 1, which is the title of an official document, contains an NG structure in the SL: the HN prezentacja (presentation) is followed by two genitives. The $\mathrm{HN}$ is in fact semantically redundant: it should be clear to the reader that the content is a presentation of the company's financial results. It follows then that head nouns in long NPs do not always need to be rendered in translation if they occur in pragmatically reconstructible contexts.

The deleted nouns in (2) and (3) are constituents of what I have termed quasipleonastic structures. Such NPs as: teren parku (the park's area) or okres Wielkiego Postu (the period of Lent) are well-formed and natural-sounding expressions in Polish. However, their heads (teren and okres) can often be omitted with hardly any semantic loss in many contexts as they are not obligatory in Polish. ${ }^{11}$ When they are embedded within longer NPs, as is the case in the above examples, such words are frequently left out in Polish-English translation for the sake of language economy and clarity. Other corpus examples of quasi-pleonastic NPs whose heads have been deleted in translation include dziedzina psychologii 
spolecznej (the fietd of social psychology ${ }^{12}$ ), grupa ptaków wodnych (the group of aquatic birds) and proces integracji językowej (the press of linguistic integration). Also note that in both sentences there are some other deletions of NP constituents. Source sentence 2 contains the full name of the park, i.e. Karkonoski Park Narodowy, which in the TL has been simplified to the Park. As this is not the first mention of the park (in fact, the sentence is part of a description of this national park), the translator decided not to repeat the full name for reasons of language economy. Regarding example 3, the abstract-sounding phrase from the SL, struktury tematyczne (literally: thematic structures), has been simplified to a single word in the TL: themes.

\section{(b) Participle deletion}

\begin{tabular}{|c|c|l|l|}
\hline No. & Corpus & \multicolumn{1}{|c|}{ Polish example } & \multicolumn{1}{|c|}{ English translation } \\
\hline 4. & CP & $\begin{array}{l}\text { Marka ORLEN stała się osią działań ko- } \\
\text { munikacyjnych i marketingowych kon- } \\
\text { cernu, co umożliwiło firmie stworzenie } \\
\text { spójnego przekazu informacji i [wiz- } \\
\text { erunkowego ujednolicenia wszystkich } \\
\text { prowadzonych działań rynkowych]. }\end{array}$ & $\begin{array}{l}\text { The ORLEN brand became the centre- } \\
\text { piece of the Company's communication } \\
\text { and marketing activities, helping PKN } \\
\text { ORLEN to create a consistent method } \\
\text { of communication and standardise [all } \\
\text { market activities in terms of brand im- } \\
\text { age]. }\end{array}$ \\
\hline 5. & RP & $\begin{array}{l}\text { W modelach Stewarta i Fergusona cen- } \\
\text { trum uwagi stanowi [synchroniczna } \\
\text { typologia języków z punktu widzenia }\end{array}$ & $\begin{array}{l}\text { In Stewart's and Ferguson's models } \\
\text { attention is focussed on [a synchronic } \\
\text { ich atrybutów i spelnianych przez } \\
\text { nie funkcji społecznych w sytuacji } \\
\text { językowej państwa] i [określenie zaj- } \\
\text { mowanych ich pozycji]. }\end{array}$ \\
$\begin{array}{l}\text { their attributes and social roles in the } \\
\text { linguistic situation of the state], and on } \\
\text { [the determination of their position]. }\end{array}$ \\
\hline
\end{tabular}

Table 2. Examples of participle deletion in Polish-English translation

This type of purposeful omission appears to be a very common translational operation and involves both present and past participles. As regards the former, a good example of present participle deletion is the already discussed NP from sentence 2 in Table 1. It contains the participial form lezacych, the genitive plural of leżacy (lying), which has not been rendered lexically in English. Both Polish sentences in Table 2 include highly complex NPs with multiple modification. All of the three boldfaced passive participles, the genitive plurals of prowadzony (conducted), spetniany (fulfilled), and zajmowany (taken) have been removed in the translation process. It appears that they contribute very little, if anything, to the overall meaning of the NPs in question, and in all likelihood have been found superfluous by the translators. Rendering these participial forms in the TL would result in somewhat awkward-sounding phrases, such as: all conducted market activities or their attributes and fulfilled social roles. 
(c) Relative clause reduction

\begin{tabular}{|c|c|c|c|}
\hline No. & Corpus & Polish example & English translation \\
\hline 6. & $\mathrm{CP}$ & $\begin{array}{l}\text { PTE PZU zarządza [OFE PZU Złota } \\
\text { Jesień, który według danych KNF, był } \\
\text { na koniec I półrocza } 2013 \text { roku trzecim } \\
\text { pod względem liczby członków (2,2 } \\
\text { mln członków) oraz pod względem ak- } \\
\text { tywów netto (36,6 mld PLN) otwartym } \\
\text { funduszem emerytalnym w Polsce]. }\end{array}$ & $\begin{array}{l}\text { PTE PZU manages [OFE PZU Złota } \\
\text { Jesien, the third largest open pension } \\
\text { fund in Poland as at the end of June } \\
\text { 2013, both in terms of its members ( } 2.2 \\
\text { million) and net assets under manage- } \\
\text { ment (PLN } 36.6 \text { billion)]. }\end{array}$ \\
\hline 7. & TG & $\begin{array}{l}\text { Warto odwiedzić [jasnogórski Arsenał, } \\
\text { w którym zgromadzono broń i archi- } \\
\text { walne dokumenty]. }\end{array}$ & $\begin{array}{l}\text { [The Arsenal on the Mount, home to } \\
\text { a collection of arms and archival docu- } \\
\text { ments], is worth a visit }\end{array}$ \\
\hline 8. & TG & $\begin{array}{l}\text { Wielką atrakcją Zakopanego jest kur- } \\
\text { sująca z Kuźnic kolejka na [Kasprowy } \\
\text { Wierch, z którego można podziwiać roz- } \\
\text { legły widok na Tatry Zachodnie z Czer- } \\
\text { wonymi Wierchami i Giewontem]. }\end{array}$ & $\begin{array}{l}\text { The cable car ride from the town's } \\
\text { Kuźnice district is a major attraction, } \\
\text { taking visitors up [Mount Kasprowy } \\
\text { Wierch, with its breathtaking view of } \\
\text { the Western Tatras, including the Czer- } \\
\text { wony Wierch and Giewont massifs]. }\end{array}$ \\
\hline
\end{tabular}

Table 3. Examples of relative clause reduction in Polish-English translation

In both Polish and English, relative clauses can be transformed to present and past participle clauses. Of interest in this subsection, however, are two other kinds of reductions: to appositives and prepositional phrases. Such transformations seem to be frequently employed by Polish-English translators.

Example 6 contains an extremely complex NP whose head, which is a company name, is postmodified by a long relative clause. In the process of translation, this clause has been converted into an appositive phrase to avoid excessive postmodification in the equivalent phrase in English. Consequently, the head noun is directly followed by another NP (the third largest open pension fund in Poland). The key NP in English is more concise than its Polish antecedent, also as a result of other deletions. ${ }^{14}$

In the remaining two examples, the Polish relative pronoun który (which) is preceded by prepositions which govern its case (hence, different suffixes in $7 \&$ 8). In theory, to render these NPs in English the translator could have employed an analogous grammatical structure. However, this would have resulted in producing clumsy phrases, such as: The Arsenal on the Mount, in which arms and archival documents have been collected, and Mount Kasprowy Wierch, from which it is possible to admire a breathtaking view of the Western Tatras, including the Czerwony Wierch and Giewont massifs. To avoid stilted and impersonal structures, the translator decided to use more economical means of expression by converting the relative clause to an appositive (sentence 7) and a prepositional phrase (sentence 8). Appositive phrases, which frequently co-occur with proper nouns, and PPs can thus be deemed viable alternatives to lengthy relative clauses introduced by prepositions. 


\subsection{Recategorization}

According to Delisle et al. (1999: 171), recategorization is "a translation procedure where equivalence in meaning or sense is established by changing the word class or part of speech of a word or phrase". Its application results in grammatical transformations, most commonly either in nominalization (deverbalization), when a verbal structure from the SL becomes nominal in the TL, or denominalization, which is the reverse operation. Thus, in Newmark's (1988) typology of translation procedures, recategorization would almost be synonymous with transposition (alternatively referred to as shift), which involves four kinds of grammatical changes. Of special interest to the ensuing analysis is the third type distinguished by Newmark (1988: 86), i.e. "the one where literal translation is grammatically possible but may not accord with the natural usage in the TL". Table 4 shows examples of such transformations with key words boldfaced.

\begin{tabular}{|c|c|l|l|}
\hline No. & Corpus & \multicolumn{1}{|c|}{ Polish example } & \multicolumn{1}{|c|}{ English translation } \\
\hline 9. & RP & $\begin{array}{l}\text { Niejednokrotnie, dopiero śledząc histo- } \\
\text { rię wspólnot komunikatywnych oraz } \\
\text { prawa wewnątrz nich rządzące, jeste- } \\
\text { śmy w stanie zrozumieć [przyczynę po- } \\
\text { wstania i zaniku języków lub zmian, } \\
\text { jakim one ulegają }\end{array}$ & $\begin{array}{l}\text { In many cases it is only by examining } \\
\text { the history of communicative networks } \\
\text { and the principles governing their de- } \\
\text { velopment that we can gain insight into } \\
\text { the reasons (why languages appear } \\
\text { and disappear, or why they change)] }\end{array}$ \\
\hline 10. & TG & $\begin{array}{l}{[\ldots] \text { królowie polscy wydali [zakaz }} \\
\text { wyrębu drzew i osadnictwa na tym te- } \\
\text { renie]. }\end{array}$ & $\begin{array}{l}{[\ldots] \text { the Polish kings (prohibited tree- }} \\
\text { felling and settling there). }\end{array}$ \\
\hline 11. & RP & $\begin{array}{l}\text { Są też dialogi, w które czynnie włącza- } \\
\text { ją się dzieci, zwłaszcza w sytuacjach, } \\
\text { gdzie zachodzi w pewnym stopniu } \\
{[\text { przewidywalność ich odpowiedzi]. }}\end{array}$ & $\begin{array}{l}\text { There are also dialogues in which chil- } \\
\text { dren actively participate especially } \\
\text { when (their answers are to some degree } \\
\text { predictable). }\end{array}$ \\
\hline 12. & CP & $\begin{array}{l}\text { Główne cele strategii PKN ORLEN: } \\
\text { [Utrzymanie dźwigni finansowej poni- } \\
\text { żej 30\%] }\end{array}$ & $\begin{array}{l}\text { Key objectives of the PKN ORLEN } \\
\text { strategy: } \\
{\left[\begin{array}{l}\text { Financial leverage maintained below } \\
\text { 30\%] }\end{array}\right.}\end{array}$ \\
\hline 13. & CP & $\begin{array}{l}\text { [Wzmocnienie kompetencji górni- } \\
\text { czych i geologicznych na wszystkich } \\
\text { szczeblach zarządzania] }\end{array}$ & $\begin{array}{l}\text { [Enhanced mining and geological } \\
\text { know-how at all levels of management } \\
\text { and production] }\end{array}$ \\
\hline
\end{tabular}

Table 4. Examples of recategorization in Polish-English translation

The above sentences are a good exemplification of different syntactic preferences and conventions in Polish and English (cf. Lewandowski 2015). Compared to English, Polish syntax is more reliant on nominal style, which is marked by a high proportion of derived nouns that often contain verb-related information. English to a larger degree favors verbal means of expression, i.e. some of the processes and qualities that in Polish are realized by noun groups are conveyed by verb phrases. Hence, Polish-English translators apply denominalization: they 
expand information packed in nouns or noun phrases in the SL into clauses in the TL. The reverse procedure is very rarely employed, at least judging by the corpus data. There are only four cases when a Polish verbal structure has been rendered by an NP in English, which is why none of them has been included in Table 4 .

The first three examples are a good illustration of what can be called 'canonical' denominalization. Most of the complex NP in sentence 9 has been expanded into a clause of reason, by changing the abstract nouns powstanie (appearance), zanik (disappearance), and zmiany (changes) into finite verbs in English. This transformation aids text comprehension as it clarifies logical relationships between sentence constituents. In sentence 10, the nominalization zakaz (ban, prohibition) has been turned into the verb prohibit. The transformed noun in the SL is preceded by the analytical verb wydać (issue), which has been deleted as a result of denominalization, and replaced with a specific verb. ${ }^{15}$ Example 11 shows that sometimes nominalizations do not have to be changed into verbs as they can also be replaced by adjectives in the translation process. Here, the noun przewidywalność (predictability) has been changed into the adjective predictable. This transformation entails some other changes, such as removing the semantically empty verb zachodzić (occur) and finding a new clause subject (their answers) in the TL sentence.

However, this corpus-driven analysis has found that denominalization does not always consist in expanding NPs into finite clauses. Examples 12 and 13 are parts of bulleted lists which are composed solely of NPs. In the former, the $\mathrm{HN}$ utrzymanie (maintenance/maintaining) is postmodified by another noun dźwignia (leverage), followed by the adjective finansowa (financial), as well as the PP ponizej 30\% (below 30\%). The English NP has a different composition, though, as its head is leverage, which is premodified by the adjective financial, and postmodified by the participial clause maintained below 30\%. Thus, the HN from the SL phrase has been changed into a non-finite verb form in the TL. The NP in example 13 has not been affected by a similar change in the order of constituents. However, the $\mathrm{HN}$ has also been revised into a past participle. In either case, the translators did not want to transfer the NG sequence from the ST into the TT as this would have added to the density of style, making the English text rather unintelligible.

\subsection{Recasting}

As Delisle et al. (1999: 171) define it, recasting is "a translation procedure where the translator modifies the order of the units in a source text in order to conform to the syntactic or idiomatic constraints of the target text". This operation is thus frequently employed when, for structural reasons, SL sentence segments cannot be rendered in the same order in the TL. Examples of recast structures are listed in Table 5. 


\begin{tabular}{|c|c|c|c|}
\hline No. & Corpus & Polish example & English translation \\
\hline 14. & $\mathrm{CP}$ & $\begin{array}{l}\text { [Zastosowana w zakładach przerób- } \\
\text { czych technika i technologia] pozwa- } \\
\text { la na [skuteczny, dochodzący nawet } \\
\text { do } 90 \% \text { odzysk miedzi oraz srebra } \\
\text { i innych pierwiastków z wydobywane- } \\
\text { go urobku, powszechnie uznawanego } \\
\text { za trudno wzbogacalny]. }\end{array}$ & $\begin{array}{l}\text { [The methods and technology used by } \\
\text { the OED facilities] provide for [the } \\
\text { effective recovery of copper, silver } \\
\text { and other minerals from the extracted } \\
\text { rock - generally considered as hard to } \\
\text { enrich]. This effectiveness is shown by } \\
\text { the high level of recovery of these met- } \\
\text { als (up to } 90 \% \text { ) }\end{array}$ \\
\hline 15. & $\mathrm{RP}$ & $\begin{array}{l}\text { [Sformulowane w powyższym tekście } \\
\text { uwagi i wnioski] są wyłącznie wstępną } \\
\text { propozycją niektórych rozwiązań meto- } \\
\text { dologicznych. }\end{array}$ & $\begin{array}{l}\text { [The discussion and conclusions for- } \\
\text { mulated in the above article] consti- } \\
\text { tute only an initial proposition for some } \\
\text { methodological solutions. }\end{array}$ \\
\hline 16. & $\mathrm{CP}$ & $\begin{array}{l}\text { [Powstające w procesach hutniczych } \\
\text { pyły ołowionośne] przerabiane są } \\
\text { na ołów. }\end{array}$ & $\begin{array}{l}\text { [The lead-bearing dust which arises } \\
\text { during the smelting process] is pro- } \\
\text { cessed into lead. }\end{array}$ \\
\hline 17. & $\mathrm{TG}$ & $\begin{array}{l}\text { Obecnie sercem sanktuarium jest } \\
\text { Wzgórze } \\
\text { ogromutników - [wywierający } \\
\text { ograżenie las krzyży]. }\end{array}$ & $\begin{array}{l}\text { Today, the heart of the sanctuary lies on } \\
\text { the Penitents' Hill, [a forest of crosses } \\
\text { that makes an enormous impression]. }\end{array}$ \\
\hline 18. & TG & $\begin{array}{l}\text { Obok wznosi się [Dwór Bractwa św. } \\
\text { Jerzego o zgrabnej, późnogotyckiej } \\
\text { sylwetce] }\end{array}$ & $\begin{array}{l}\text { Alongside the gate stands [the elegant } \\
\text { Late Gothic Mansion of the Brother- } \\
\text { hood of St. George]. }\end{array}$ \\
\hline
\end{tabular}

Table 5. Examples of recasting in Polish-English translation

The above examples perfectly exemplify the structural differences between complex Polish and English NPs. The premodifiers in sentences 14-17 contain categories that cannot occur in attributive position in English. As was argued in section 2, in Polish syntax, unlike in English, HNs can be premodified by prepositional phrases and structures including adverb and object combinations. In English, these categories can only be used in post-head position. Consequently, in the case of the first four sentences, the translators have shifted the premodifiers to postnominal position.

Sentence 14 contains two complex NPs. In the first one, the HNs, technika and technologia (the methods and technology), are premodified by a past participle clause including the prepositional phrase $w$ zaktadach przeróbczych (by the OED facilities). In the English translation, the whole premodifier has been moved to postnominal position. The head noun in the other NP, odzysk (recovery) is preceded by two modifiers: the general adjective skuteczny (effective) and the present participle clause dochodzacy nawet do $90 \%$ (reaching up to 90\%). As in this case the head noun is followed by lengthy modifiers, the translator decided to leave the first modifier in pre-head position and render the content of the participle clause in an extra sentence to avoid excessive postmodification. Sentence 15 is a classic example of recasting: the whole premodifier containing a prepositional phrase has been shifted to postnominal position in the English translation. 
Sentences 16 and 17 illustrate a slightly different kind of recasting. In both cases the Polish premodifiers have been turned into postmodifiers in the English NPs. The Polish HNs, i.e. pyty and las (dust and forest), are preceded by present participle clauses, which include a preposition (example 16) and an object (example 17). For this very reason, these clauses cannot occur in pre-head position in English. However, there is yet another structural change involved here. The translators have revised the shifted present participle clauses into adjectival clauses, which, according to Biber et al. (1999: 606), are the second most common type of postmodification after PPs. Based on three examples (notably, 2, 16 and 17), it can be generalized that in some contexts present participles tend to be avoided in Polish-English translation: they are either deleted or expanded into relative clauses. ${ }^{16}$

In sentence 18, the reverse procedure has been applied. The proper name Dwór Bractwa św. Jerzego (Mansion of the Brotherhood of St. George) is followed by a prepositional phrase. The semantic information contained in this postmodifier has been shifted to prenominal position. Yet in fact, in the translation of this NP, all of the three procedures under investigation have been employed simultaneously. Besides recasting, the translator applied recategorization (for structural reasons, the prepositional phrase from the SL has been changed into an adjectival phrase ${ }^{17}$ ) and reduction (the noun sylwetka has not been rendered by any equivalent English word).

\section{Conclusion}

Based on the overview of the structural differences between Polish and English NPs and on the analysis of translation examples, it can be concluded that in the three registers in question, most transformations concern three types of SL modifiers: 1) postmodifying nouns (usually in the genitive), 2) complex premodifiers that include PPs and/or object and adverb combinations, and 3) elaborate relative clauses (especially when they are introduced by prepositions). As shown in the previous section, these potentially challenging structures can successfully be rendered in the TL through the application of such translation procedures as: NP reduction, recategorization and recasting.

While the above-mentioned methods are sometimes combined, with example 18 being a good case in point, it can be argued that the most commonly employed structural modification involves a decrease in the number of NP constituents, and most typically affects nouns, participles and relativizers. As suggested by Delisle et al. (1999: 127), similar concentration tendencies can generally be observed in translation into English from many languages. Evidently, by deleting redundant words, phrases and structures, translators strive to produce more economical and natural-sounding prose, which is in line with the stylistic and syntactic conventions of the TL. Besides purely structural reasons, there seems to be yet another factor that comes to the fore: sometimes, translators need to include culturally- 
relevant information to familiarize target readers with concepts or phenomena, which SL readers usually take for granted (example 8, in which the translator added culture-specific information, is a good illustration of this operation). ${ }^{18}$ Hence, in some cases, purely structural changes aimed at achieving language economy can be additionally motivated by the need to convey supplementary information, which is essential to the proper understanding of the text by a TL audience.

The present contribution has been designed to emphasize the relevance of contrastive grammar approaches in translation studies as well as to raise the awareness of the structural differences between Polish and English among translation scholars, practitioners and students. Hopefully, some of the paper's findings can be successfully applied in the early stages of translation training.

\section{Notes}

1 The full list of abbreviations is provided at the end of this paper.

2 In Polish linguistics, the status of appositives is debatable. For example, Kallas (1980) argues that they are subordinated to the preceding NP while Gębka-Wolak (1999) claims that they have equivalent status with their antecedents.

According to Biber et al. (1999: 606), the most frequent kinds of postmodification in English are (in descending order): prepositional phrases, relative clauses, past participle clauses, present participle clauses, and appositives.

Polish lacks articles as a grammatical category though their occurrence can sometimes by indicated by indefinite or demonstrative pronouns, e.g. jakiśsjakaś/jakieś (some) or ten/ ta/to (this) (cf. Willim and Mańczak-Wohlfeld 1997: 90). For insights into article-related translation problems see Douglas-Kozłowska (2012).

5 Exceptions include phrases such as auto myjnia (car wash) or biznes plan (business plan). However, these structural borrowings are criticized by Polish language purists and prescriptive linguists as flouting the norm.

6 If an equivalent Polish NP is used in a sentence, such as Ona miała szanse wygrać (ten) wyścig (She had a chance to win the race), the noun szansa in the accusative is directly followed by an infinitive. However, as Gębka-Wolak (2000: 51) convincingly argues, in such structures the infinitive wygrać is in fact dependent on the verb phrase mieć szanse (have a chance) rather than on the noun itself.

7 For example, Szwedek (1981: 49-61), drawing largely on Szober's (1963) views, claims that word order in Polish is not an element of sentence structure, but of text structure and reflects the distribution of new vs given information. A detailed treatment of the factors governing word order in Polish goes beyond the scope of the present article. For this purpose, the Jasnopis web-based application (available at http://jasnopis.pl/aplikacja) has been used. However, some authors (cf., e.g., Baker 2011: 42-43), define omission in different terms, and view it as a legitimate translation procedure, which should be used as a last resort, though. The following example from German-English translation serves as a good illustration of this point: Die deutsche Bahn und die Amtrak, die staatliche Eisenbahngesellschaft für den Personenverkehr der USA, einigten sich auf eine auf eine Probe des ICE $\rightarrow$ German Rail and Amtrak agreed to test the ICE high-speed train. The underscored appositive from the ST, whose English translation would be the US public passenger rail service, has been left out in translation as it includes redundant information for a US reader (Delisle et al. 1999: 145). 
from Table 1. The revised Polish examples would read (changes, involving different case endings and one of the prepositions, are indicated in bold): Spośród najbardziej znanych skatek leżacych $\boldsymbol{w}$ Karkonoskim Parku Narodowym najciekawsze sa Pielgrzymy and W'́ród kompleksów pytajnych powtarzają się struktury tematyczne związane z Wielkim Postem. Strikethrough indicates the English equivalents of the deleted words.

13 In this case, the Polish and English NPs exhibit one more structural difference, which results from the application of another translation procedure: recategorization (see the next subsection for more details). The head of the Polish NP, the deverbal noun ujednolicenie (standardization) in the translation process has been turned into the verb standardize, which is obviously not a constituent of the English NP.

14 The Polish NP contains redundancies which have been omitted in translation. In the source sentence, the PP pod względem (in terms of) and the genitive of the noun czlonkowie (members) occur twice, while their English equivalents are used only once. The noun liczba (number) from the phrase liczba czlonków (the number of members) has not been rendered in the English translation, either. The rationale here is that the meanings of the deleted words and phrases can easily be inferred. The phrase wedtug danych KNF (according to the PFSA data) has been left out as well. Here, the translator clearly deemed it unnecessary to quote the source of information (PFSA - the Polish Financial Supervision Authority), as it has already been supplied earlier on, at the beginning of the article. If the translator had tried to provide an exact equivalent of this collocation, she would have produced a somewhat stilted phrase, such as: imposed a ban on tree-felling and settling. This assumption is at least partially confirmed by Biber et al. (1999: 631), who argue that in contemporary English non-fiction registers -ed clauses are much more common than -ing clauses.

In the corpus there are several other examples of postmodifying prepositional phrases turned into attributive adjectives as a result of translation, e.g. profesjonalista o wysokich kompetencjach - highly-competent professional, Kościót Najświętszego Serca Pana Jezusa $\boldsymbol{z}$ dwiema wiezami - twin-towered Church of the Most Sacred Heart of Jesus, and proces integracji wspólnoty komunikatywnej pod względem jezzykowym - the process of linguistic integration of the network.

In translation theory this procedure is known as explicitation (cf. Delisle et al. 1999: 139).

\section{References}

Baker, Mona (2011) In other words: A coursebook on translation. London: Routledge.

Biber, Douglas (2003) “Compressed noun phrase structures in newspaper discourse.” In: Aitchison, Jean and Diana M. Lewis (eds.) New Media Language. London: Routledge, 169-181.

Biber, Douglas, Stig Johansson, Geoffrey Leech, Susan Conrad and Edward Finegan (1999) The Longman Grammar of Spoken and Written English. London: Longman.

Delisle, Jean, Hannelore Lee-Jahnke and Monique C. Cormier (1999) Terminologie de la Traduction. Translation Terminology. Terminología de la Traducción. Terminologie der Übersetzung. Amsterdam: John Benjamins Publishing.

Douglas-Kozłowska, Christian (2012) The Articles in Polish-English Translation: Przedimek w języku angielskim. Warszawa: Państwowe Wydawnictwo Naukowe.

Fisiak, Jacek, Maria Lipińska-Grzegorek and Tadeusz Zabrocki (1978) An introductory EnglishPolish contrastive grammar. Warszawa: Państwowe Wydawnictwo Naukowe.

Gajda, Stanisław (2001) "Styl naukowy.” In: Bartmiński, Jerzy (ed.) Współczesny język polski. Lublin: Wydawnictwo UMCS, 183-199.

Gębka-Wolak, Małgorzata (1999) "O możliwości interpretowania grup apozycyjnych z członem wyodrębnionym interpunkcyjnie jako konstrukcji współrzędnych.” Poradnik Językowy 1, 21-29. 
Gębka-Wolak, Małgorzata (2000) Związi linearne między składnikami grupy nominalnej we współczesnym języku polskim. Toruń: Wydawnictwo Uniwersytetu Mikołaja Kopernika.

Halliday, M. A. K. (1994) An Introduction to Functional Grammar. London: Edward Arnold.

Jodłowski, Stanisław (1976) Podstawy polskiej składni. Warszawa: Wydawnictwo Naukowe PWN.

Kallas, Krystyna (1980) Grupy apozycyjne we wspótczesnym języku polskim. Toruń: Uniwersytet Mikołaja Kopernika.

Konefał, Ewa (2013) "Strategie kompresyjno-kondensacyjne w przekładzie tekstu medialnego." In: Żarski Waldemar (ed.) Kondensacja i kompresja w języku, tekstach i kulturze. Wrocław: Oficyna Wydawnicza ATUT - Wrocławskie Wydawnictwo Oświatowe, 71-91.

Kucelman, Ewa (2012) "The structure of the noun phrase in English and Polish." In: Misztal, Mariusz and Mariusz Trawiński (eds.) Annales Universitatis Pedagogicae Cracoviensis. Studia Anglica II. Kraków: Wydawnictwo Naukowe UP, 109-117.

Lewandowski, Marcin (2015) "On denominalization in Polish-English translation. Implications for translation teaching." Lebende Sprachen 60 (1), 145-163.

Libura, Maria (2000) "Jak obraz świata odbija się w gramatyce? Analiza języka fizyki klasycznej.” In: Dąbrowska, Anna and Janusz Anusiewicz (eds.) Język a kultura vol. 13. Wrocław: Wydawnictwo Uniwersytetu Warszawskiego, 125-130.

Majchrzak, Konrad (1978) The structure of the noun phrase in English and Polish: A contrastive analysis (unpublished $\mathrm{PhD}$ dissertation). Poznań.

Newmark, Peter (1988) A textbook of translation. New York: Prentice Hall.

Quirk, Randolph, Sydney Greenbaum, Geoffrey Leech and Jan Svartvik (1985) A comprehensive grammar of the English language. London and New York: Longman.

Radovanović, Milorad (2001) "On nominal and verbal style: cultures or languages in contact?" International Journal of the Sociology of Language 151, 41-48.

Schäffner, Christina (2000) "Running before walking? Designing a translation program at undergraduate level." In: Schäffner, Christina and Beverly Adab (eds.) Developing translation competence. Amsterdam: John Benjamins Publishing Company, 143-157.

Scheffler, Paweł (2008) "Formal grammar or functional sentence perspective? Some remarks about word order in Polish." Zeszyt Naukowy Instytutu Neofilologii Państwowej Wyższej Szkoły Zawodowej w Koninie 5, 83-89.

Szober, Stanisław (1963) Gramatyka języka polskiego. Warszawa: Państwowe Wydawnictwo Naukowe.

Szwedek, Aleksander (1981) Word order, sentence stress and reference in English and Polish. Bydgoszcz: Wydawnictwo Uczelniane WSP.

Willim, Ewa and Elżbieta Mańczak-Wohlfeld (1997) A contrastive approach to problems with English. Warszawa and Kraków: Państwowe Wydawnictwo Naukowe.

\section{Translation corpus sources}

\section{Research papers (RP)}

Marcinkiewicz, Józef (2000) "Processes of linguistic integration in the Grand Duchy of Lithuania in the light of the theory of communicative networks and other sociolinguistic concepts." In: Hasiuk, Michał and Grzegorz Błaszczyk (eds.) Linguistic and Oriental Studies from Poznań, Monograph Supplement 5. Poznań: Wydawnictwo Naukowe UAM, 47-63 (translated by Piotr Gąsiorowski; Polish manuscript provided by the author).

Grzelak, Eliza (2014) "Functional differences in the language of religion." In: Mikołajczak, Stanisław and Małgorzata Rybka (eds.) The Language of Religion, Past and Present. Poznań: Wydawnictwo Naukowe UAM, 41-47 (translated by Reisner, Ryszard J. and Piotr T. Żebrowski). Originally published as: Grzelak, Eliza (2005) "Zróżnicowanie funkcjonalne języka religijnego.” In: Mikołajczak, Stanisław and Fr. Tomasz Węcławski (eds.) Język religijny dawniej i dziś II. Poznań: Wydawnictwo "Poznańskie Studia Polonistyczne", 39-45. 
Lizak, Jadwiga (2014) “The Language of Sermons for Children.” In: Mikołajczak, Stanisław and Małgorzata Rybka (eds.) The Language of Religion, Past and Present. Poznań: Wydawnictwo Naukowe UAM, 93-101 (translated by Reisner, Ryszard J. and Piotr T. Żebrowski). Originally published as: Lizak Jadwiga (2005) “Język kazań dla dzieci.” In: Mikołajczak, Stanisław and Fr. Tomasz Węcławski (eds.) Język religijny dawniej i dziś II. Poznań: Wydawnictwo "Poznańskie Studia Polonistyczne", 152-158.

\section{Company profiles (CP)}

http://www.orlen.pl/PL/Strony/default.aspx

http://www.orlen.pl/en/pages/default.aspx

$\mathrm{http} / / / \mathrm{kghm} . \mathrm{com} /$

http://kghm.com/en

https://www.pzu.pl/

https://www.pzu.pl/en

All websites retrieved on June 30, 2015 (source text authors and translators unknown).

\section{Tourist guide (TG)}

Bąk, Jolanta, Jacek Bronowski, Ewa Ressel and Marek Zygmański (2012) Polska. Poland. Bielsko-Biała: Wydawnictwo Dragon (translated by Caryl Swift, ATOMINIUM Biuro Tłumaczeń Specjalistycznych).

\section{List of abbreviations (in alphabetical order)}

$\mathrm{CP}$ - company profiles

$\mathrm{HN}$ - head noun

$\mathrm{NG}-$ noun + genitive

$\mathrm{NP}$ - noun phrase

$\mathrm{PP}$ - prepositional phrase

$\mathrm{RP}$ - research papers

$\mathrm{SL}$ - source language

ST - source text

$\mathrm{TG}$ - tourist guide

$\mathrm{TL}$ - target language

TT - target text

Marcin Lewandowski, Ph.D, is assistant professor at the Institute of Linguistics, Adam Mickiewicz University in Poznań, Poland. His main areas of research include sociolinguistics (predominantly sociolectal and registerial variation), cognitive linguistics and translation studies. Besides several papers, he has published two books: the first one explores the language of the punk subculture while the other one is an English-Polish contrastive study of football language.

Address: Dr. Marcin Lewandowski, Institute of Linguistics, Adam Mickiewicz University, Al. Niepodleglości 4, 61-874 Poznań, Poland. [email: marcinl@amu.edu.pl] 